\title{
The impact of online marketing on the use of textile packaging: an approach to consumer behaviour
}

DOI: $10.35530 / I T .072 .02 .202019$

\author{
STEFAN-CLAUDIU CAESCU \\ FLORINA BOTEZATU \\ RALUCA-GIORGIANA CHIVU
}

IONUT-CLAUDIU POPA

MARGARETA STELA FLORESCU

\begin{abstract}
REZUMAT
The impact of online marketing on the use of textile packaging: an approach to consumer behaviour

Online marketing is the act of utilizing online channels and tools to spread a message or idea about an organization's image, items, or administrations to its potential clients. The strategies and methods used for Internet showcasing incorporate email, online networking, show promoting, website streamlining, Google AdWords, and that's just the beginning.

Online marketing has become more and more used in recent years, whether it is about promoting products or services, or it is about ideas, concepts, and beliefs. Considering this aspect, this article aims to identify the influence of online communications on the adoption or acceptance by consumers of products packaged in textiles. In recent years there has been a significant discussion in the literature on the role and purpose of packaging (promotion, product protection, advertising), but they have not highlighted consumer preferences for packaging and the impact of online marketing on them.
\end{abstract}

Keywords: attributes of packaging, behaviour influences, marketing concept, online marketing, textile packaging

Impactul marketingului online asupra utilizării ambalajelor textile: o abordare a comportamentului consumatorului

\begin{abstract}
Marketingul online este actul de a utiliza canale și instrumente online pentru a distribui un mesaj sau o idee despre imaginea, articolele sau informațiile administrative ale unei organizații către clienții potențiali ai acesteia. Strategiile și metodele utilizate pentru prezentarea pe internet includ e-mail marketing, rețele online, promovarea prin evenimente, eficientizarea site-ului web, Google AdWords și multe altele.

Marketingul online a devenit din ce în ce mai utilizat în ultimii ani, fie că este vorba despre promovarea produselor sau serviciilor, fie despre idei, concepte, credințe. Având în vedere acest aspect, prezentul articol își propune să identifice influența comunicărilor online asupra adoptării sau acceptării de către consumatori a produselor ambalate în materiale textile. În ultimii ani, a existat un interes semnificativ în literatura de specialitate cu privire la rolul și scopul ambalajului (promovare, protecția produselor, publicitate), dar nu a evidențiat preferințele consumatorilor pentru ambalaje și impactul marketingului online asupra acestora.
\end{abstract}

Cuvinte-cheie: atribute ale ambalajului, influențe ale comportamentului, concept de marketing, marketing online, ambalaje textile

\section{INTRODUCTION}

In a world where consumers are increasingly adopting online shopping habits, marketing strategies are consequently adapting to this trend, with online marketing increasing its versatility as well. Considering this, the present research aims to address the impact of online marketing on the acceptance of textile packaging, by identifying the factors playing a role in the changes in consumer's behaviour and establishing the determinants.

Marketing is an essential part of any business or idea, and without solid marketing goals and the right strategy for achieving them, a company cannot grow and will not be resilient in the market in the long run. With the advances of our society, especially the Internet, many online promotion tools and techniques are now available to any organization and have often proven to be more profitable than the traditional marketing tools used for decades. As a result, according to Kotler \& Keller [1], online marketing channels are increasingly important not only in building and consolidating brands, but in increasing sales as well and as Popescu [2] asserts, "in the face of a dynamic, ever-changing environment, the modern organization must seek to adapt to its evolution".

Thus, according to Negricea [3], online communication has advantages for consumers and marketers, the Internet enabling direct interaction between consumers with common interests not only between producer and consumer. Furthermore, Negricea [3] observed that the marketing specialist benefits from the emergence of new sales channels, targeted messaging, measurability, continuous availability of messages, interactive dialogue with the consumer, personalization of the offer, loyalty, while the consumer 
enjoys advantages such as ease of online activity, continuous availability of the offer, a wide range of information sources, access to other customer reviews, fundamental decisions, quick and even realtime response, information available on request, as well as a high degree of satisfaction.

The most important online marketing tools are online advertising, email marketing, search marketing, newsgroups (social media), website and blog marketing. In addition, "on a variety of digital platforms, a wide range of consumer engagement practices have evolved, including, for example, advertising games, reading (and writing) customer reviews, and watching, appreciating, and distributing consumer videos, brand, blogs" [4].

"Online advertising is any form of impersonal communication, paid or compensated by barter, through which information about products, services, ideas or values are transmitted by an identifiable organization or person, through the website or by email [3]. Thus, "the Internet has become a media vehicle for sponsored communications" [5], which are now almost daily or even daily in the life of an Internet user.

Email marketing summarizes all communications, commercial or not, initiated by a company with the help of email and aim to strengthen and maintain the relationship with the consumer, developing and managing the database [3]. Data on current and potential customers enables an increase in the conversion rate and in reach via promotional messages or public information about the company. Newsletters fulfil several tasks such as: remembering the company's presence, providing information to the consumers, increasing brand credibility, facilitating online ordering for the organization's products or services, and obtaining customer feedback [6].

A website is an online marketing tool without which the virtual presence of the company would be severely affected and is "the basis of internet marketing" [7]. The website must be designed in a way that facilitates its navigation and provides an effortless experience for the visitor. A well-structured website influences users to take as many actions as possible. The site informs and promotes the company's products or services.

\section{GENERAL INFORMATION ABOUT CONSUMER BEHAVIOUR AND ONLINE MARKETING INFLUENCES}

Since the end of the year, the term online marketing and social media have developed significantly [8]. There is another type of promotion that focuses on offering new potential advertisements to advertisers to provide information regarding a good or service. This contrasts with the usual average impact across other communication channels, mainly due to the possibility of feedback from other buyers through reviews [8]. Buyer behaviour is a significant part of advertising, as it helps advertisers safely design promotional campaigns for the target group.
Millions of dollars are spent on marketing trying to study consumers' behaviour and to influence what, when and how they consume. This kind of knowledge enables a versatile marketing research. A TV commercial can be annoying when it interrupts a favourite show, but it can also be an excellent source of information on the target audience and on the underlying behavioural assumptions. Indeed, given the pervasive nature of advertisements, understanding how they try to influence consumers is essential in understanding our environment [9].

Consumer behaviour is a form of manifestation and of the decision process of the human behaviour in general. As a result of this marketing component, the action of explain consumer behaviour was defined by specialists in several ways, none of which enjoyed universal significance. In a narrow sense, consumer behaviour reflects people's preference in buying, consuming material goods and services as well as their stance on certain social aspects. It encompasses the entire conduct of the end-user of tangible and intangible assets [10].

The theory of the psychological and social network offers a considerable promise for improving our understanding of internet marketing in several dimensions.

First, the Internet is an environment through which consumers interact, communicate and respond. The theory of the psychological and social network thus provides an essential framework for correlating internal and social decision-making processes.

Second, the Internet is complex and requires an understanding of consumers' existing attitudes, beliefs, and social interactions that manifest and then transfer from the store to their online experiences.

Third, because many shopping experiences are based on impact, the Internet is a composite of visual, individual, and interpersonal stimuli. Eventually, the Internet is increasingly becoming a social environment through which consumers seek and share information with others.

In general, information processing has been and should continue to be a key topic in Internet marketing. The way consumers process, evaluate and respond to the stimuli of the information they are exposed to is an essential source of theoretical and applied materials for web designers and users.

Research examining information processing, learning and attitude formation in the context of mobile communications, multiple marketing communications, integrated communication channels, social content and user-generated content is particularly justified [11].

Consumers may prefer information through experience, rather than search, even when the experience is expensive. Searching can sometimes be even more expensive. For example, in purchasing most appliances, consumers face this problem.

Determining by inspection the time flow of services from alternative brands of a device is extremely difficult. Therefore, the experience could be used as a cheaper information procedure. 
We assume that, although we have experienced in brands of the same product, the consumer can certainly determine the preferred brand among them. Moreover, the favourite brand will remain so over time. This is also true for adopting changes to already known products and ideas. We still believe that the only way to experience the difference is to buy it. As in the case of search, the consumer should obtain information through experience until the marginal cost of the data becomes more significant than his marginal profitability.

Online marketing has led to significant changes in consumer behaviour in terms of access to information and news, changes caused mainly by changes in factors that contribute to shaping online consumer behaviour such as increasing knowledge about a particular product or service or identifying a new need. This is due to the relevance of marketing research that shows that web experience generates changes in mental processes that trigger the decision to adopt ideas much faster. Therefore, marketers should recognize the importance of studying the factors that influence online consumer behaviour and their growing power in the digital world.

Various types of factors influence consumer behaviour. For the most part, traders cannot control these factors, but they must take them into account. Traders need to understand both the theory and the reality of consumer behaviour.

Web experience includes elements such as researching, browsing, finding, selecting, comparing and evaluating alternatives, as well as interacting and trading with that particular company influenced by web page design. The purpose of these elements is to attract consumers and change the outcome of online interaction.

The most representative psychological factor that influences consumers' online behaviour is online perception. Perception is the process of interpretation by which consumers understand their environment. Many people believe that attitude is passive; that is, you can see and hear what is there objectively. However, people actively perceive stimuli and objects in the environment, including the online world. At the same time, perception is an approximation of reality. The brain tries to make sense of the stimuli to which it is exposed.

Personality greatly influences online consumer behaviour. In the online environment, consumers may have different characters compared to everyday life; they can use their ego to communicate in different personalities or mixed identities. Social networks are full of ideas designed by people to increase their chances of socializing with another virtual environment, and marketers focus on the visual and auditory characteristics of a product or service to connect with the inner part of the consumer and identity/virtual identities. [12]

Online strategies should first focus on the market segment with a high degree of involvement in Internet marketing, such as students or business professionals with a high level of education and income.
By providing more information about products, customer service and convenient payment methods, internet marketing can help increase the frequency of online shopping and money spent. The online purchase rate is limited by low revenue. To reach these consumers, the online marketing manager should emphasize the promotion of the company and the promotion of products through advertising. As increased trust and, ultimately, use, the implementation of more information and development can stimulate the use and rates of online shopping [13].

\section{TEXTILE PACKAGING - NEW MARKETING CONCEPT}

The package represents the science, quality and innovation of framing or securing items for circulation, storage, trading and use. The package contains, insures, blocks, ships, lights and sells. Customers consider the quality of the item and its ease of use; however, they also appreciate the package plan of an item when purchasing a particular product.

The package of an item is more than a way of assurance and capacity, assuming the first impact for a buyer when buying an item (packaging design, handling), thus fulfilling one of the main purposes when purchasing a good (content protection, ease The packaging and its characteristics are an essential factor because package components, such as package shading, foundation image, package material, text style, cover structure, printed data and development, are considered important factors in selling an item. Packaging plays a crucial role in the visual presentation of the product, especially in the retail sector (where packaging is visible and accessible for analysis by shopping) and could be treated as one of the most significant elements to have an impact on the buyer's choice.

As Rundh [14] points out, the package stands out for the consumer of a specific brand, contributing to the improvement of the image and the recognition of an item by the comparator. In this way, the package plays an important place in the presentation of correspondence and could be treated as one of the most significant variables that affect the buyer's choice. Packaging encourages buyers to choose the item from the full range of comparable items, practically contributing to the formation of the decision to purchase a particular good or brand. According to Kotler [1], there are six components that must be evaluated when using package options: size, structure, material, shading, content and brand.

Renaud [15] analysed the elements of brand and product legitimacy, as well as purchasing behaviour. Packaging/labelling has a relative significance when contrasted with other properties of the item, such as rating systems used in consumer buying behaviour (e.g., if a consumer is familiar with a particular product, it will not change preferences depending on the packaging of other similar products).

According to Prathiraja [16], when a buyer ponders purchasing options, their choice often gravitates 
towards the marking on the items, especially if they recognize it. Many buyers are willing to pay extra if the information on the package is trustworthy. Nutrition labelling can be considered a method of promotion used to provide customers with relevant data on the nutritional values of the product. There are consumers who do not appreciate a substance added to a product (for obtaining functional foods), because in general, buyers are convinced of the content of the supplement, depending on the promotion, the general messages of well-being and their knowledge in food sciences. As Jeddi pointed out [17], packaging made of cheap materials such as polyolefin filaments, have modified the standard materials used for packaging, generating the creation of advanced strategies and applications for packaging and labelling. The high quality and consistency of the designed materials, combined with modern materials that contribute to the promotion strategies have allowed the adaptation of packaging used in mass production, for protection, efficient handling and increasingly efficient circulation capacity in the case of powdered contents and granules, raw materials, composts, sand concrete, sugar, flour and dyes. Lighter clothing, including nonwovens, such as wet, glued fabrics, is used as packaging in the food industry, in the transportation of medicines and the protection of electronic parts. Leather belts and materials are generally used for bonding and include high thickness polyethylene, low thickness polyethylene, polypropylene, biaxially located polypropylene, polystyrene, polycarbonate, polyester, nylon and fluoropolymers. Depending on the idea of the item to be incorporated and the type of material used, the grouping may be called dynamic incorporation, aseptic package, which maintains the food grouping, clinical/pharmaceutical package, a grouping of hazardous substances and new package (sales label) [18].

\section{MODELLING THE CONSUMER'S BEHAVIOR REGARDING THE ACCEPTANCE OF TEXTILE PACKAGING}

Modelling of the consumer's behaviour regarding the acceptance of packaging made of textile materials represents the analysis of the factors that contribute to the formation of the preference and the adoption of the new proposed packaging. The research methodology consisted on one hand (if later "on the other hand" is used), in conducting quantitative research among consumers to identify issues such as time spent online, the attention they pay to online advertising, the perceived impact that online marketing has on purchasing and consumption decisions, and on the adoption of textile packaging. On the other hand, quantitative research also identified the aspects that consumers consider useful and necessary in packaging and the conditions under which they might adopt or create a preference for packaging made of textiles.

The tool used in quantitative research was a questionnaire consisting of 25 questions, six of which were related to identification and classification. For modelling by structural equations, the least-squares technique and the WarpPls program were used (modelling by structural equations was performed using the least-square technique and the WarpPis program). Modeling by structural equations is a multivariable measurable examination method that is used to dissect and analyze primary connections. This involves investigating the links between the factors involved and generating sustained links. From a mathematical point of view through the auxiliary association between the estimated factors and the inactive development. Researchers favor this strategy because it assesses dependence and dependent relationships in an individual survey.

The impact of online marketing on consumers' decisions to accept packaging from textiles is achieved by testing each link proposed in the conceptual model (figure 1). For each arrow marked with an $\mathrm{Hx}$,

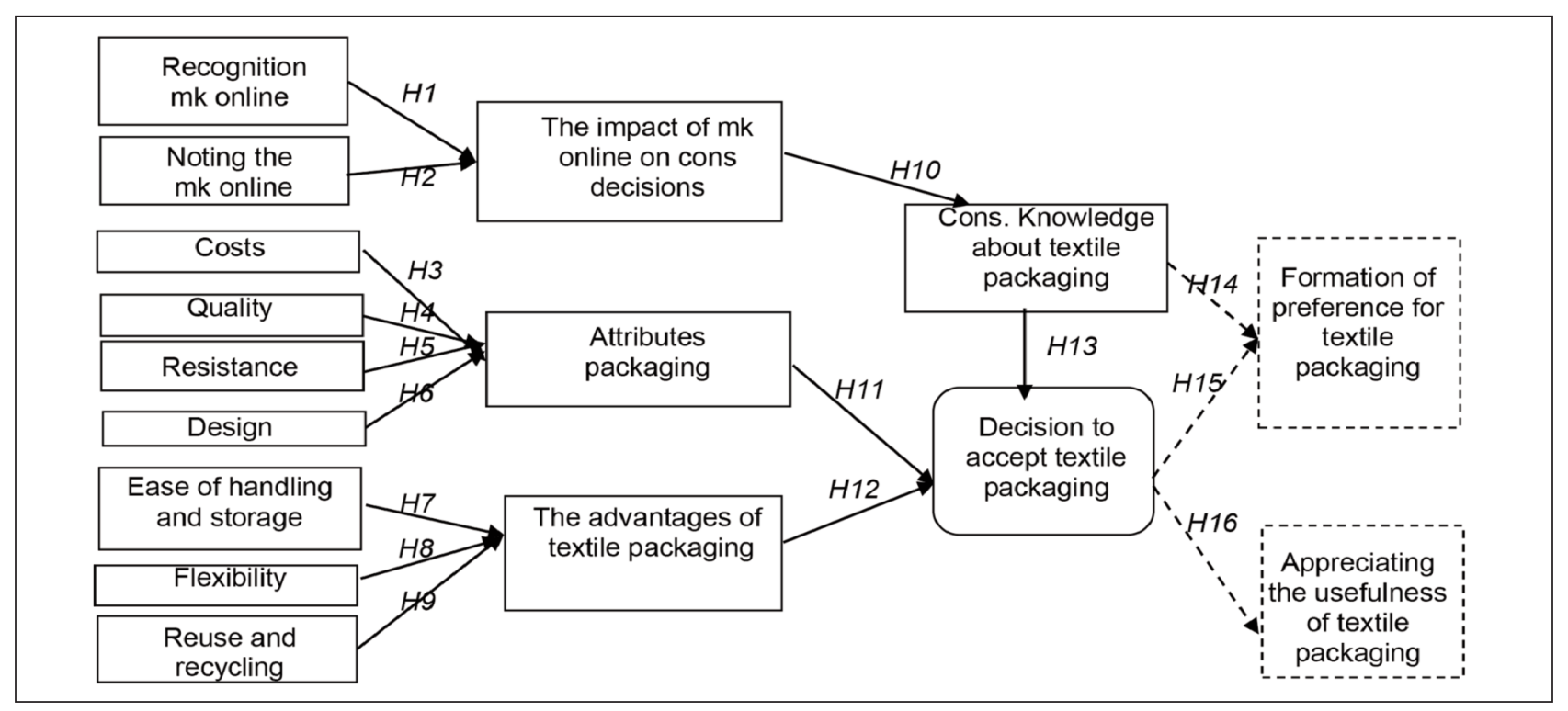

Fig. 1. A conceptual model for Consumer's behaviour regarding the acceptance of textile packaging 


\begin{tabular}{|c|c|c|c|c|}
\hline \multicolumn{5}{|c|}{ VALIDATION OF THE MAIN HYPOTHESES OF THE PROPOSED CONCEPTUAL MODEL } \\
\hline Hypotheses & Main hypothesis & $\beta$ & $\mathbf{p}$ & Validation \\
\hline $\mathrm{H} 1$ & $\begin{array}{l}\text { Recognition marketing online } \rightarrow \text { The impact of marketing online on cons. } \\
\text { decisions }\end{array}$ & 0.67 & $<0.01$ & Yes \\
\hline $\mathrm{H} 2$ & $\begin{array}{l}\text { Noting the marketing online } \rightarrow \text { The impact of marketing online on cons. } \\
\text { decisions }\end{array}$ & 0.42 & $<0.01$ & Yes \\
\hline $\mathrm{H} 3$ & Costs $\rightarrow$ Attributes packaging & 0.66 & $<0.01$ & Yes \\
\hline $\mathrm{H} 4$ & Quality $\rightarrow$ Attributes packaging & 0.51 & $<0.01$ & Yes \\
\hline H5 & Resistance $\rightarrow$ Attributes packaging & 0.28 & $=0.04$ & Yes \\
\hline $\mathrm{H} 6$ & Design $\rightarrow$ Attributes packaging & 1.08 & $<0.01$ & Yes \\
\hline$H 7$ & Ease of handling and storage $\rightarrow$ The advantages of textile packaging & 0.13 & $=0.08$ & No \\
\hline H8 & Flexibility $\rightarrow$ The advantages of textile packaging & 0.01 & $=0.46$ & No \\
\hline $\mathrm{H} 9$ & Reuse and recycling $\rightarrow$ The advantages of textile packaging & 0.32 & $<0.01$ & Yes \\
\hline $\mathrm{H} 10$ & $\begin{array}{l}\text { The impact of marketing online on cons decisions } \rightarrow \text { Cons. Knowledge about } \\
\text { textile packaging }\end{array}$ & 0.85 & $<0.01$ & Yes \\
\hline $\mathrm{H} 11$ & Attributes packaging $\rightarrow$ Decision to accept textile packaging & 0.23 & $<0.01$ & Yes \\
\hline $\mathrm{H} 12$ & The advantages of textile packaging $\rightarrow$ Decision to accept textile packaging & 0.54 & $<0.01$ & Yes \\
\hline $\mathrm{H} 13$ & $\begin{array}{l}\text { Cons. Knowledge about textile packaging } \rightarrow \text { Decision to accept textile } \\
\text { packaging }\end{array}$ & 0.35 & $<0.01$ & Yes \\
\hline $\mathrm{H} 14$ & $\begin{array}{l}\text { Cons. Knowledge about textile packaging } \rightarrow \text { Formation of preference for } \\
\text { textile packaging }\end{array}$ & 0.90 & $<0.01$ & Yes \\
\hline$H 15$ & $\begin{array}{l}\text { Decision to accept textile packaging } \rightarrow \text { Formation of preference for textile } \\
\text { packaging }\end{array}$ & 0.08 & $=0.18$ & No \\
\hline H16 & $\begin{array}{l}\text { Decision to accept textile packaging } \rightarrow \text { Appreciating the usefulness of textile } \\
\text { packaging }\end{array}$ & 0.31 & $<0.01$ & Yes \\
\hline
\end{tabular}

there is an objective and a related hypothesis according to which there is a direct link between the two connected aspects.

The main hypotheses of the research correspond to the descriptions of the relationships between the latent components of the proposed model (table 1). These are tested by calculating the binding coefficients (Beta-standardized coefficients) corresponding to each causal relationship in the model. The value of the Beta coefficients indicates the strength and the direction of the correlation between the variables (specify which variables) while the validation of the hypotheses are materialized when the value of the related Beta coefficient is higher than 0.1 at a significance threshold $p<0.05$ [19].

From the results, we can see that most of the proposed hypotheses have been validated efficiently, there are direct and positive links between two variables related to the proposed conceptual model. The invalidated hypotheses support the idea that consumers do not consider the "possibility of handling and storage" and "flexibility of use" as significant advantages of products packaged in textiles, but also that decision or preference for products packaged in dexterous materials are not necessarily formed.

Below you can see the diagram of the conceptual model generated by the analysis program by WarpPLS structural equations (figure 2).

\section{CONCLUSIONS}

The Internet and its ever-evolving technologies have influenced the way customers and vendors interact in the marketplace. Technology has been and will continue to be an engine of Internet marketing. Although several articles have studied the involvement of consumers in the decision to advertise products and purchase, little research has involved internet marketing. The theory of consumer behaviour has become in the last quarter of a century, especially after the emergence of the modern concept of marketing, a distinct and essential area of marketing. The evolution of the ways of approaching consumer behaviour is marked by the achievements obtained over time in terms of human knowledge in general, the explanatory answer on consumer reactions in certain situations and their decision-making processes, being treated from a sociological point of view, psychological or economic, which reflects an abundance of concepts and interpretations. Hence the numerous classifications and influencing factors determined in the research of consumer behaviour.

Such concepts have been successfully applied in the present research with the objective to analyse the impact of online marketing on acceptance of textile packaging. As a conclusion, we can consider that online marketing has a significant impact on consumer decisions in general, and on decisions to 


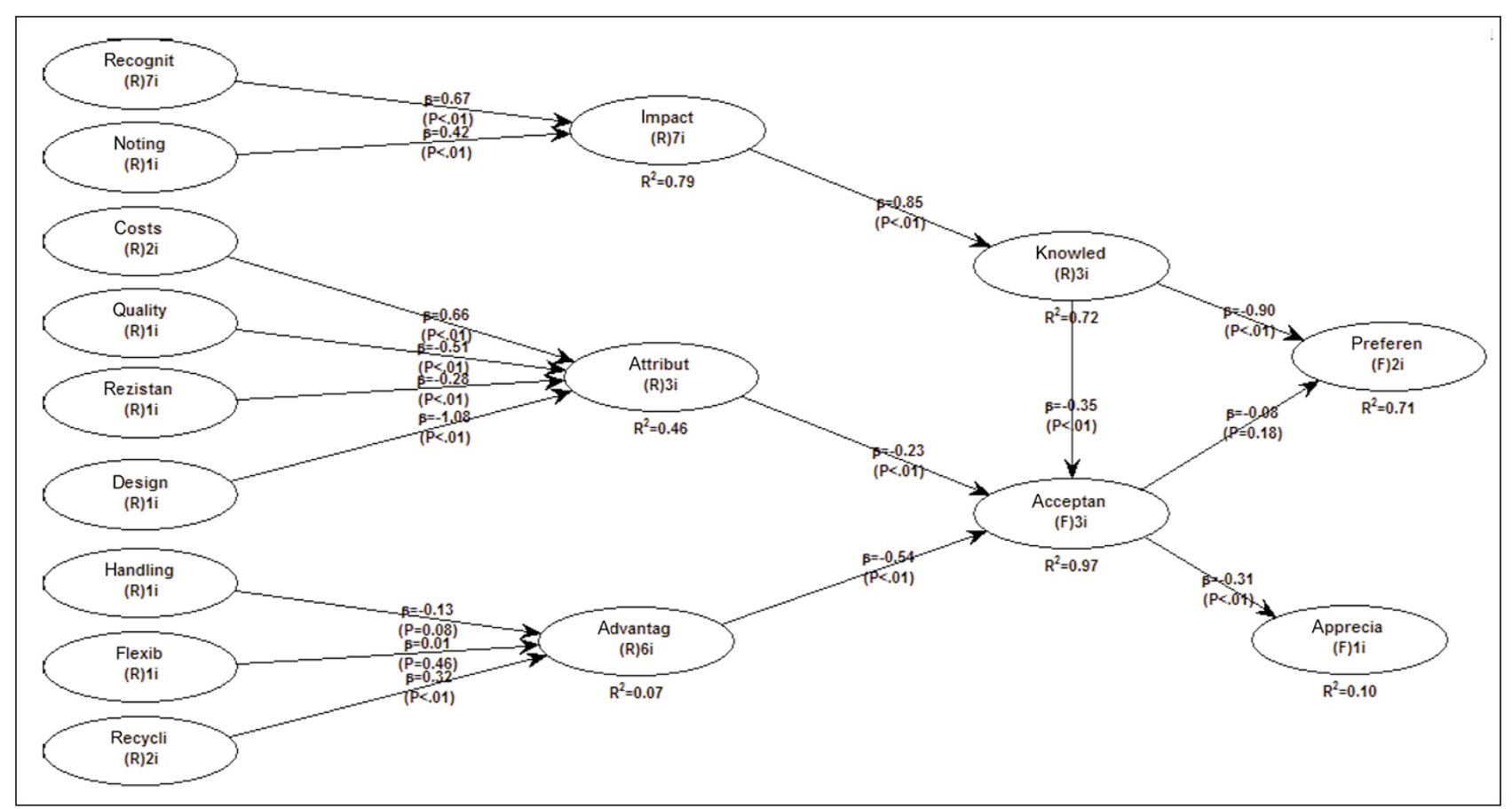

Fig. 2. Validated model for Consumer's behaviour regarding the acceptance of textile packaging (WarpPLS)

adopt and use products packaged in textiles in particular, highlighting again the role that online communications and information have on consumer behaviour. Online marketing, as we have seen in the research, is easily noticed by consumers, and they feel they have a significant level of influence on future decisions. In the same way, the information from the online environment regarding the packaging made of textile materials contributes directly to the acquisition of knowledge, to the decision to accept them and to the development of preferences for this type of packaging and their advantages.

\section{REFERENCES}

[1] Kotler, P., Keller, K.L., Marketing Management, 14th Edition, New Jersey: Prentice-Hall Publishing House, 2012

[2] Popescu, I.C., Communication in marketing - concepts, techniques, strategies, Second Edition revised and added, Bucharest: Uranus Publishing House, 2003

[3] Negricea, I.C., Online Marketing Strategies: successful solutions for the development and implementation of online marketing applications in the organization's activity, Bucharest: University Publishing House, 2010

[4] Eigenraam, A.W., Eelen, J., Van Lin, A., Verlegh, P.W.J., A Consumer-based Taxonomy of Digital Customer Engagement Practices, In: Journal of Interactive Marketing, 2018, 44, 102-121, Available at: https://www.sciencedirect.com/science/article/pii/S1094996818300495 [Accessed on May 2020]

[5] Sharma, R., Alavi, S., Ahuja, V., Generating trust using Facebook - A study of 5 online apparel brands, In: Procedia Computer Science, 2017, 122, 42-49, Available at: https://www.sciencedirect.com/science/article/pii/ S1877050917325681 [Accessed on May 2020]

[6] Hudak, M., Kianickova, E., Madlenak, R., The importance of email marketing in e-commerce, In: Procedia Engineering, 2017, 192, 342-347, Available at: http://www.sciencedirect.com/science/article/pii/ S187770581732605X [Accessed on May 2020]

[7] Madlenak, R., Madleeakova, L., Svadlenkab, L., Salava, D., Analysis of Website Traffic Dependence on Use of Selected Internet Marketing Tools, In: Procedia Economics and Finance, 2015, 23, 123-128, Available at: https://www.sciencedirect.com/science/article/pii/S221256711500355X [Accessed on May 2020]

[8] Zarrella, D., The Social Media Marketing Book, O'Reilly Media, 2009

[9] Hawkins, D.I., Mothersbaugh, D.L., Customer behavior. Building marketing strategy, 11th edition, United States: Library of Congress Cataloging, 2010

[10] Balaure, V. (coordinator), Adăscăliței, V., Bălan, C., Boboc, Ș., Cătoiu, I., Olteanu, V., Pop, N.A., Teodorescu, N., Marketing, 2nd Edition, Bucharest: Uranus Publishing House, 2002

[11] Cummins, S., Peltier, J.W., Schibrowsky, J.A., Nill, A., Consumer behavior in the online context, In: Journal of Research in Interactive Marketing, 2014, 8, 3, 169-202, Available at: https://www.emeraldinsight.com/doi/ pdfplus/10.1108/JRIM-04-2013-0019 [Accessed on May 2020]

[12] Cetină, I., Munthiu, M.C., Rădulescu, V., Psychological and social factors that influence online consumer behavior, In: Procedia - Social and Behavioral Sciences, 2012, 62, 184-188, Available at: https://www.sciencedirect.com/ science/article/pii/S1877042812034702 [Accessed on May 2020] 
[13] Wu, I., Internet marketing involvement and consumer behavior, In: Asia Pacific Journal of Marketing and Logistics, 2002, 14, 4, 36-53, Available at: https://www.emeraldinsight.com/doi/pdfplus/10.1108/13555850210764945 [Accessed on May 2020]

[14] Rundh, B., The multi-faceted dimension of packaging, In: British food journal, 2005

[15] Renaud, I., The influence of label on wine consumption: its effects on young consumers' perception of authenticity and purchasing behavior, Bologna, Italy, 2007

[16] Prathiraja, P.H.K., Ariyawardana, A., Impact of nutritional labelling on consumer buying behavior, In: Sri Lankan Journal of Agricultural Economics, 2003, 5 (1381-2016-115752), 35-46

[17] Jeddi, N., The Impact of Label Perception on the Consumers' Purchase Intention: An application on food products, In: IBIMA business review, 2010

[18] Dhandapani, Sharma, D.C., Textiles for packaging, 2005, 14, 31-34

[19] Orzan, G., Platon, O.E., Stefănescu, C.D., Orzan, M., Conceptual Model Regarding the Influence of Social Media Marketing Communication on Brand Trust, Brand Affect and Brand Loyalty, In: Economic Computation \& Economic Cybernetics Studies \& Research, 2016, 50, 1

\section{Authors:}

\section{STEFAN-CLAUDIU CAESCU ${ }^{1}$, FLORINA BOTEZATU1 ${ }^{1}$, RALUCA-GIORGIANA CHIVU ${ }^{1}$, IONUT-CLAUDIU POPA ${ }^{1}$, MARGARETA STELA FLORESCU ${ }^{2}$}

${ }^{1}$ Bucharest University of Economic Studies, Faculty of Marketing,

Bvd. Dacia no. 41, 010374, Bucharest, Romania e-mail: stefan.caescu@mk.ase.ro, botezatuflor@gmail.com, popa.claudiu3@yahoo.com

${ }^{2}$ Bucharest University of Economic Studies, Faculty of Public Administration and Management,

Piata Romana, no. 6, 010374, Bucharest, Romania

e-mail: margareta.florescu@ari.ase.ro

\section{Corresponding author:}

RALUCA-GIORGIANA CHIVU

e-mail: raluca.chivu0126@gmail.com 